\title{
A Grand Challenge: Unbiased Phenotypic Function of Metabolites from Jaspis splendens against Parkinson's Disease
}

Dongdong Wang, ${ }^{\dagger}$ Yunjiang Feng, ${ }^{\dagger}$ Mariyam Murtaza, ${ }^{\dagger}$ Stephen Wood, ${ }^{\dagger}$ George Mellick, ${ }^{\dagger}$ John N. A. Hooper, ${ }^{\ddagger}$ and Ronald J. Quinn* ${ }^{\dagger}$

${ }^{\dagger}$ Eskitis Institute for Drug Discovery, Griffith University, Brisbane, QLD 4111, Australia

‡Queensland Museum, South Brisbane, QLD 4101, Australia

\section{Supporting Information}

ABSTRACT: A grand challenge in natural product chemistry is to determine the biological effects of all natural products. A phenotypic approach is frequently used for determining the activity of a compound and its potential impact on a disease state. Chemical investigation of a specimen of Jaspis splendens collected from the Great Barrier Reef resulted in the isolation of a new pterin derivative, jaspterin (1), a new bisindole alkaloid, splendamide (2), and a new imidazole alkaloid, jaspnin A (3) TFA salt. Jaspamycin (8) and 6-bromo- $1 \mathrm{H}$-indole-3-carboximidamide (16) are reported for the first time as naturally occurring metabolites. Known nucleosides $(4-7,9,10)$, aglycones (11-13), indole alkaloids $(14,15,17)$, and jaspamide peptides $(18-22)$ were also isolated. The structures of the three new compounds 1-3 were unambiguously elucidated based on NMR and mass spectroscopic data. Jaspnin A (3) contained a rare thiomethylated imidazolinium unit. Coupling an unbiased phenotypic assay using a human olfactory neurosphere-derived cell model of Parkinson's disease to all of the natural products from the species J. splendens allowed the phenotypic profiles of the metabolites to be investigated.

A grand challenge in natural product chemistry is to determine the biological effects of all natural products. Target-based drug discovery approaches provide efficient and high capacity in testing unprecedented numbers of compounds and molecular targets utilizing advances in automation, biochemistry, structural biology, and chemistry-related technologies. ${ }^{1}$ High-throughput screening (HTS), however, has lower hit rates. Target screening also heavily relies on knowledge of known therapeutic pathways. In addition, other pathways or functional proteins affected by compounds may not be identified by target-based screening. New molecular entities identified by phenotypic screening approved by the FDA outnumbered target-based approaches during this time frame between 1999 and 2008 (37\% versus 23\%). ${ }^{2}$ In comparison, phenotypic screening has the advantage of the whole organism being exposed to compounds and interrogates all targets and biological pathways. When multiple parameters are examined, a multidimensional cytological profiling method can be used to cluster compounds.

Parkinson's disease is the second most common neurodegenerative disease, affecting over five million patients worldwide $^{3}$ and in the majority of cases has no clearly identifiable cause. Like Alzheimer's disease, it mostly affects the elderly and causes considerable disability and suffering. There is no effective drug available to cure this progressive disease. Thus, there is an urgent need to develop new therapeutic agents. Nontransformed and nonimmortalized human olfactory

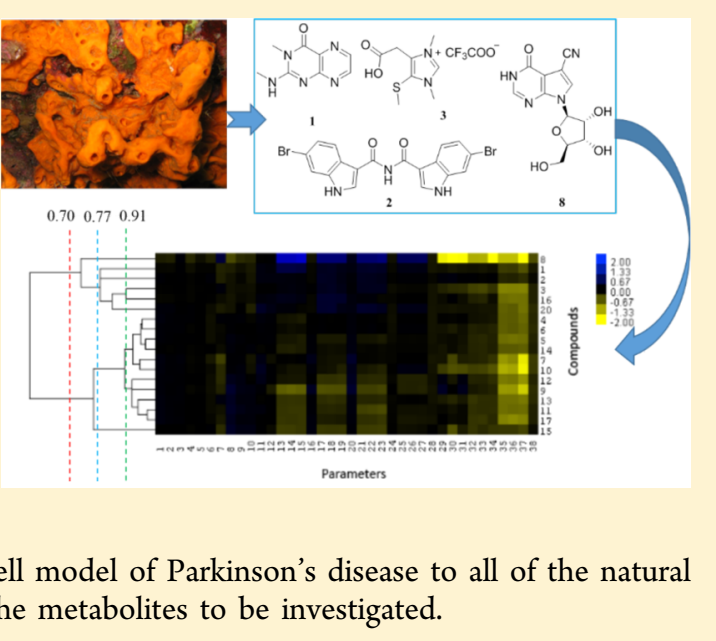

neurosphere-derived (hONS) cells, which are primary cells derived from Parkinson's disease patients, model functional aspects of Parkinson's disease. ${ }^{4-6}$ Coupling an unbiased phenotypic assay using the hONS cell model of Parkinson's disease to an analysis of all natural products from one species could allow phenotypic profiles of all the metabolites to be investigated.

As part of a research program aiming to identify antiParkinson's disease lead compounds, a marine sponge, Jaspis splendens, collected from the Great Barrier Reef was selected from Nature Bank. ${ }^{7-9}$ Sponges of the genus Jaspis (family Ancorinidae) have been a rich source of structurally novel, biologically active natural products. ${ }^{10}$ Over 150 natural products have been isolated from the genus including antifungal, anthelmintic, catatonic, insecticidal, and ichthyotoxic jaspamide peptides, ${ }^{11-13}$ antineoplastic and cytotoxic isomalabaricane triterpenes, ${ }^{14-16}$ cytotoxic macrolides, ${ }^{17}$ antifungal, antiparasitic, and cytotoxic bengazoles, ${ }^{18,19}$ antiparasitic, antimicrobial, and cytotoxic bengamides, ${ }^{20-22}$ cytotoxic bromotyrosine derivatives, ${ }^{23,24}$ anticandidal and cytotoxic nucleosides, ${ }^{25}$ and a series of dihydroxystyrene sulfate derivatives. ${ }^{26-28}$

Chemical investigation of a specimen of J. splendens resulted in the isolation and characterization of 22 secondary metabolites, including a new pterin derivative, jaspterin (1), a

Received: November 1, 2015

Published: February 17, 2016 
new bisindole alkaloid, splendamide (2), a new methylthioimidazole-containing alkaloid, jaspnin A (3) trifluoroacetic acid (TFA) salt, and jaspamycin (8) and 6-bromo- $1 \mathrm{H}$-indole-3carboximidamide (16), previously reported as synthetic products, ${ }^{29}$ together with 17 known natural products, namely, guanosine (4), ${ }^{30}$ 6-deoxyguanosine $(5),{ }^{31}$ thymidine (6), ${ }^{32}$ toyocamycin (7), ${ }^{25}$-(methoxycarbonyl)tubercidin (9), ${ }^{25}$ sangivamycin (10), ${ }^{33}$-(methoxycarbonyl)tubercidin aglycone $(11),{ }^{25}$ toyocamycin aglycone $(12),{ }^{25}$ sangivamycin aglycone (13), ${ }^{34}$ 6-bromotryptamine (14), ${ }^{35}$ 6-bromo- $1 \mathrm{H}$-indole-3-carboxamide (15), ${ }^{36}$-bromo- $1 \mathrm{H}$-indole-3-carboxylic acid methyl ester $(\mathbf{1 7}){ }^{37}$ jaspamide $(\mathbf{1 8}),^{38}$ jasplakinolide B (19), ${ }^{39}$ jaspamide $\mathrm{Z}_{1}(\mathbf{2 0}),{ }^{40}$ jasplakinolide $\mathrm{F}(\mathbf{2 1}),{ }^{11}$ and pipestelide A (22). ${ }^{41}$

All compounds were subjected to an unbiased phenotypic assay on hONS cells followed by cluster analysis of cytological effects. Based on previous work, we had developed a theoretical framework that explains that all natural products interact with biologically relevant space. ${ }^{42,43}$ Herein we report the isolation and structure elucidation of the five new natural compounds ( 1 , 2, 3, 8, and 16) as well as the phenotypic effects of all isolated natural products from $J$. splendens.

\section{RESULTS AND DISCUSSION}

The ground and freeze-dried J. splendens $(50 \mathrm{~g}$ ) was sequentially extracted with $n$-hexane, $\mathrm{CH}_{2} \mathrm{Cl}_{2}$, and $\mathrm{MeOH}$. The $\mathrm{CH}_{2} \mathrm{Cl}_{2}$ / $\mathrm{MeOH}$ extracts were combined and fractionated using a $\mathrm{C}_{18}$ bonded silica flash column and a stepwise $\mathrm{H}_{2} \mathrm{O} / \mathrm{MeOH} / 0.1 \%$ TFA gradient. Five fractions were collected by eluting with $\mathrm{H}_{2} \mathrm{O}, 90 \% \mathrm{H}_{2} \mathrm{O} / 10 \% \mathrm{MeOH}, 50 \% \mathrm{H}_{2} \mathrm{O} / 50 \% \mathrm{MeOH}, 10 \%$ $\mathrm{H}_{2} \mathrm{O} / 90 \% \mathrm{MeOH}$, and $\mathrm{MeOH}$, respectively (each containing $0.1 \%$ TFA). Further purification of the $90 \% \mathrm{H}_{2} \mathrm{O} / 10 \% \mathrm{MeOH}$ fraction by $\mathrm{C}_{18}$ bonded silica HPLC (gradient $\mathrm{H}_{2} \mathrm{O} / \mathrm{MeOH}$ with $0.1 \%$ TFA) resulted in the isolation of three new metabolites, namely, jaspterin (1), jaspnin A (3) TFA salt, and jaspamycin $(8)$, together with nucleosides $(4-7,9,10)$ and aglycones (11-13). Previous studies of indole alkaloids by our group have revealed that the exchangeable $\mathrm{NH}$ proton typically manifests between $\delta_{\mathrm{H}} 10.0$ and 12.0 in deuterated DMSO. ${ }^{44,45}$ The ${ }^{1} \mathrm{H}$ NMR spectrum in DMSO- $d_{6}$ of the $50 \% \mathrm{H}_{2} \mathrm{O} / 50 \%$ $\mathrm{MeOH}$ fraction displayed exchangeable $\mathrm{NH}$ proton signals between $\delta_{\mathrm{H}} 10.00$ and 12.00 together with aromatic signals between $\delta_{\mathrm{H}} 7.00$ and 8.50 , indicating the presence of indole alkaloids. HPLC purification of the fraction yielded a new bisindole alkaloid, splendamide (2), and a new indole alkaloid, 6-bromo- $1 H$-indole-3-carboximidamide (16), along with three known indole alkaloids $(\mathbf{1 4}, \mathbf{1 5}, \mathbf{1 7})$. The ${ }^{1} \mathrm{H}$ NMR spectrum of the $10 \% \mathrm{H}_{2} \mathrm{O} / 90 \% \mathrm{MeOH}$ fraction contained some intriguing signals indicative of peptidic-type molecules. Further purification of the fraction led to the isolation of five jaspamide peptides $(\mathbf{1 8 - 2 2})$. In total, 22 structurally diverse natural products were isolated from the prolific sponge J. splendens.

Jaspterin (1) was isolated as a white power. (+)-HRESIMS data gave a $[\mathrm{M}+\mathrm{Na}]^{+}$ion at $m / z$ 214.0670, which was consistent with a molecular formula of $\mathrm{C}_{8} \mathrm{H}_{9} \mathrm{~N}_{5} \mathrm{O}$ with seven degrees of unsaturation. The IR spectrum had absorption bands at 1680 and $1630 \mathrm{~cm}^{-1}$, suggesting carbonyl functionalities in the molecule. The ${ }^{1} \mathrm{H}$ NMR spectrum included two deshielded aromatic doublets $\left(\delta_{\mathrm{H}} 8.68\right.$ and 8.40$)$, one methyl singlet $\left(\delta_{\mathrm{H}}\right.$ $3.40)$, one methyl doublet $\left(\delta_{\mathrm{H}} 2.96\right)$, and one broad exchangeable doublet $\left(\delta_{\mathrm{H}} 7.54\right)$ (Table 1$)$. Analysis of the HSQC and HMBC spectra indicated that the molecule contained one amide carbonyl signal $\left(\delta_{\mathrm{C}} 160.7\right)$, five aromatic
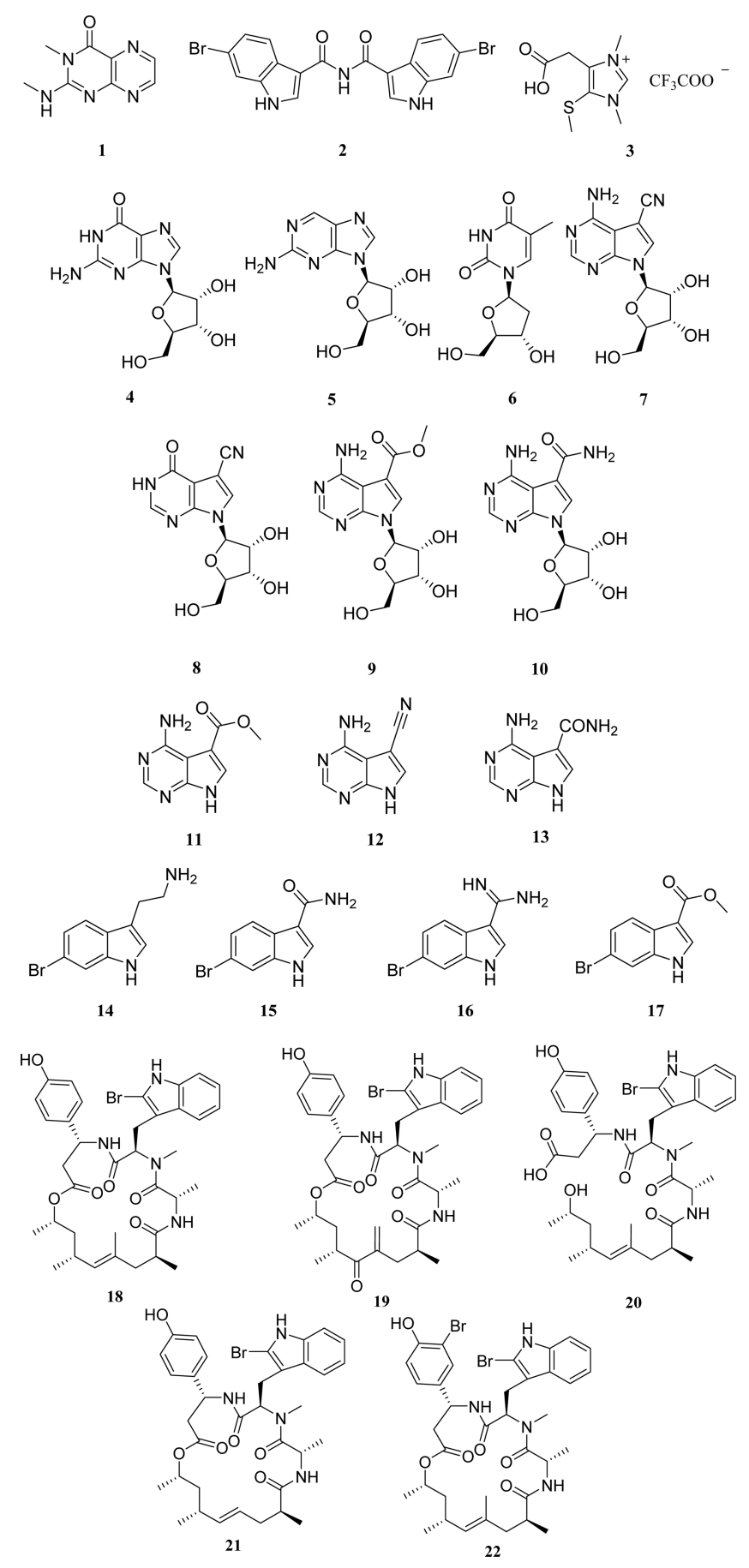

carbons $\left(\delta_{\mathrm{C}} 155.2,153.3,149.5,139.0\right.$, and 128.1), and two methyl carbons $\left(\delta_{\mathrm{C}} 28.5\right.$ and 28.2$)$. The chemical shifts of the two methyls $\left(\delta_{\mathrm{H}} 3.40\right.$ and $\delta_{\mathrm{C}} 28.2, \delta_{\mathrm{H}} 2.96$ and $\left.\delta_{\mathrm{C}} 28.5\right)$ indicated that they were both $N$-methyl groups.

The UV spectrum of 1 showed absorption maxima at 280 and $358 \mathrm{~nm}$ (broad), indicative of a pyrazine moiety. The small coupling constant $(J 1.5 \mathrm{~Hz})$ between the two methine doublets $\left(\delta_{\mathrm{H}} 8.48\right.$ and 8.68$)$ and their deshielded carbon chemical shifts $\left(\delta_{\mathrm{C}} 139.0\right.$ and 149.5$)$ suggested the two protons belonged to $\mathrm{H}-6$ and $\mathrm{H}-7$ in the pyrazine moiety. HMBC correlations from H-6 $\left(\delta_{\mathrm{H}} 8.48\right)$ to C-4a and C-7 $\left(\delta_{\mathrm{C}} 128.1\right.$ and 149.5$)$ and from H-7 $\left(\delta_{\mathrm{H}} 8.68\right)$ to C-6 and C-8a $\left(\delta_{\mathrm{C}} 139.0\right.$ and 155.2$)$ confirmed the assignment. $\mathrm{HMBC}$ correlations were observed from the aminomethyl protons to the nonprotonated carbon $\left(\delta_{\mathrm{C}} 153.3\right)$, suggesting the $\mathrm{CH}_{3} \mathrm{NH}-$ functionality was attached at the C-2 
Table 1. NMR Spectroscopic Data $\left(600 \mathrm{MHz}\right.$ for ${ }^{1} \mathrm{H}$ and 150 $\mathrm{MHz}$ for ${ }^{13} \mathrm{C}$, DMSO- $d_{6}$ ) for 1

\begin{tabular}{lllll} 
position & \multicolumn{1}{c}{$\delta_{\mathrm{C}}$, type } & $\delta_{\mathrm{H}}$, mult. $(J$ in $\mathrm{Hz})$ & COSY & HMBC $^{a}$ \\
\hline 2 & $153.3, \mathrm{C}$ & & & \\
4 & $160.7, \mathrm{C}$ & & & \\
$4 \mathrm{a}$ & $128.1, \mathrm{C}$ & & & \\
6 & $139.0, \mathrm{CH}$ & $8.40, \mathrm{~d}(1.5)$ & $\mathrm{H}-7$ & $4 \mathrm{a}, 7$ \\
7 & $149.5, \mathrm{CH}$ & $8.68, \mathrm{~d}(1.5)$ & $\mathrm{H}-6$ & $6,8 \mathrm{a}$ \\
$8 \mathrm{a}$ & $155.2, \mathrm{C}$ & & & \\
$9-\mathrm{NH}$ & & $7.54, \mathrm{~d}(5.0)$ & $\mathrm{H}-10$ & \\
10 & $28.5, \mathrm{CH}_{3}$ & $2.96, \mathrm{~d}(5.0)$ & $\mathrm{NH}$ & 2 \\
11 & $28.2, \mathrm{CH}_{3}$ & $3.40, \mathrm{~s}$ & & 2,4
\end{tabular}

${ }^{a} \mathrm{HMBC}$ correlations are from proton(s) stated to the indicated carbon.

position. Further HMBC correlations from the second $\mathrm{N}$ methyl $\left(\delta_{\mathrm{H}} 3.40\right)$ to the same nonprotonated carbon $\left(\delta_{\mathrm{C}} 153.3\right)$ as well as an amide carbonyl carbon $\left(\delta_{\mathrm{C}} 160.7\right)$ indicated an isocytosine moiety. With all the atoms accounted for and the degrees of unsaturation satisfied, the structure of $\mathbf{1}$ was established (Figure 1).

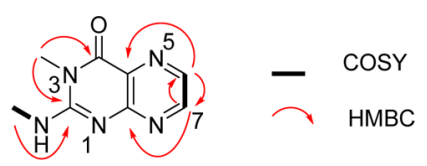

Figure 1. Key COSY and HMBC correlations for $\mathbf{1}$.

Jaspterin (1) closely resembles pterins, a class of naturally occurring compounds biosynthesized from guanosine triphosphate in all living organisms. ${ }^{46}$ Pterins were first discovered in the pigments of butterfly wings. Biopterin and neopterin were also reported from human urine. ${ }^{46,47}$ This class of compounds plays an important role in amino acid hydroxylation, and they also act as cofactors in enzyme catalysis. In the field of heterocyclic chemistry pterins owe their exceptional position mainly to their unusual chemical properties and their conspicuous fluorescence.

Splendamide (2) was isolated as a colorless gum. (+)-LRESIMS for 2 displayed an isotopic cluster of ions [M $+\mathrm{H}]^{+}$at $m / z 459,461$, and 463 in the ratio of 1:2:1, indicating the presence of two bromines. The adduct ion in the (+)-HRESIMS spectrum at $\mathrm{m} / z 481.9116[\mathrm{M}+\mathrm{Na}]^{+}$allowed the molecular formula to be assigned as $\mathrm{C}_{18} \mathrm{H}_{11}{ }^{79} \mathrm{Br}_{2} \mathrm{~N}_{3} \mathrm{O}_{2}$, which was consistent with 14 degrees of unsaturation. The IR spectrum had absorption bands at $1683 \mathrm{~cm}^{-1}$, indicating an amide functionality in the molecule. The ${ }^{1} \mathrm{H}$ NMR data (Table 2) contained four aromatic methines $\left(\delta_{\mathrm{H}} 8.40,8.06,7.69\right.$, and 7.32) and two sharp exchangeable protons $\left(\delta_{\mathrm{H}} 11.99\right.$ and 10.34). Analysis of the HSQC and HMBC spectra indicated the molecule contained a carbonyl carbon $\left(\delta_{\mathrm{C}} 167.8\right)$ and eight aromatic carbons $\left(\delta_{\mathrm{C}} 137.3,132.2,125.8,123.8,122.3,114.9\right.$, 114.5 , and 110.0).

The UV spectrum had absorption maxima at $216 \mathrm{~nm}$ and a broad band around $272 \mathrm{~nm}$, indicative of an indole moiety. $\mathrm{HMBC}$ correlations from the $\mathrm{NH}\left(\delta_{\mathrm{H}} 11.99\right)$ to the methine carbon C-7 $\left(\delta_{\mathrm{C}} 114.5\right)$ and the nonprotonated carbon C-3 $\left(\delta_{\mathrm{C}}\right.$ $110.0)$ and from the methine proton $\mathrm{H}-2\left(\delta_{\mathrm{H}} 8.40\right)$ to the nonprotonated carbons C-3a and C-7a $\left(\delta_{\mathrm{C}} 125.8\right.$ and 137.3) established the presence of a 6-substituted indole-3-yl moiety (Figure 2). The assignment was confirmed by HMBC
Table 2. NMR Spectroscopic Data $\left(600 \mathrm{MHz}\right.$ for ${ }^{1} \mathrm{H}$ and 150 $\mathrm{MHz}$ for ${ }^{13} \mathrm{C}$, DMSO- $d_{6}$ ) for 2

\begin{tabular}{|c|c|c|c|c|}
\hline position & $\delta_{\mathrm{C}}$, type & $\begin{array}{l}\delta_{\mathrm{H}}, \text { mult. } \\
\text { in } \mathrm{Hz})\end{array}$ & COSY & $\mathrm{HMBC}^{a}$ \\
\hline $1,1^{\prime}$ & & 11.99, bs & $\mathrm{H}-2, \mathrm{H}-2^{\prime}$ & $3 a, 3 a^{\prime}, 7,7^{\prime}$ \\
\hline $2,2^{\prime}$ & 132.2, $\mathrm{CH}$ & $8.40, \mathrm{~d}(3.0)$ & $\mathrm{H}-1, \mathrm{H}-\mathrm{1}^{\prime}$ & $\begin{array}{c}3,3^{\prime}, 3 a, 3 a^{\prime}, 7 a \\
7 a^{\prime}, 8,8^{\prime}\end{array}$ \\
\hline $3,3^{\prime}$ & 110.0, C & & & \\
\hline $3 a, 3 a^{\prime}$ & 125.8, C & & & \\
\hline $4,4^{\prime}$ & $122.3, \mathrm{CH}$ & $8.06, \mathrm{~d}(8.5)$ & H-5, H-5' & $3,3^{\prime}, 6,6^{\prime}, 7 a, 7 a$ \\
\hline $5,5^{\prime}$ & 123.8, CH & $\begin{array}{l}\text { 7.32, dd (1.8, } \\
8.5)\end{array}$ & $\begin{array}{l}\mathrm{H}-4, \mathrm{H}-7, \mathrm{H}- \\
4^{\prime}, \mathrm{H}-7^{\prime}\end{array}$ & $\begin{array}{l}3 \mathrm{a}, 3 \mathrm{a}^{\prime}, 7,7^{\prime}, 7 \mathrm{a}, \\
7 \mathrm{a}^{\prime}\end{array}$ \\
\hline $6,6^{\prime}$ & 114.9, C & & & \\
\hline $7,7^{\prime}$ & 114.5, CH & $7.69, \mathrm{~d}(1.8)$ & H-5, H-5' & $\begin{array}{l}3 a, 3 a^{\prime}, 5,5^{\prime}, 7 a, \\
7 a^{\prime}\end{array}$ \\
\hline $7 a, 7 a^{\prime}$ & 137.3, C & & & \\
\hline $8,8^{\prime}$ & 167.8, C & & & \\
\hline 9 & & $10.34, \mathrm{~s}$ & & $8,8^{\prime}$ \\
\hline
\end{tabular}

${ }^{a}$ HMBC correlations are from proton(s) stated to the indicated carbon.

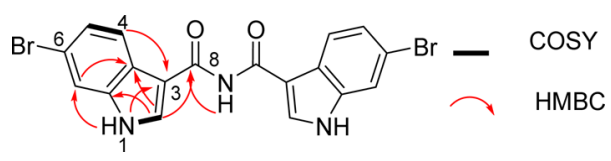

Figure 2. Key COSY and HMBC correlations for 2.

correlations from the methine proton $\mathrm{H}-4\left(\delta_{\mathrm{H}} 8.06\right)$ to the nonprotonated carbons C-3, C-6, and C-7a $\left(\delta_{\mathrm{C}} 110.0,114.9\right.$, and 137.3) and from the methine proton $\mathrm{H}-7\left(\delta_{\mathrm{H}} 7.69\right)$ to the methine carbon $\mathrm{C}-5\left(\delta_{\mathrm{C}} 123.8\right)$ and the nonprotonated carbon C-3a $\left(\delta_{\mathrm{C}}\right.$ 125.8). A bromine substitution at position 6 was confirmed due to its carbon chemical shift $\left(\delta_{\mathrm{C}} 114.9\right)$. Further $\mathrm{HMBC}$ correlations were observed from a methine proton $\left(\delta_{\mathrm{H}}\right.$ $8.40)$ and the second exchangeable proton $\left(\delta_{\mathrm{H}} 10.34\right)$ to a carbonyl carbon $\left(\delta_{\mathrm{C}} 167.8\right)$, indicating an amide group at the C-3 position. So far only half of the molecular formula was accounted for. On the basis of the observation of a relatively deshielded chemical shift of the amide proton $\left(\delta_{\mathrm{H}} 10.34\right)$ together with its integration as half a proton compared with other proton signals, and the requirement of 14 degrees of unsaturation, 2 was assigned as a dimeric imide structure (Figure 2).

Indole-3-carboximidamides are rarely encountered in nature. Wuzhuyurutine A from Evodia rutaecarpa (Juss.) Benth. (Rutaceae $)^{48}$ and $N$-(aminocarbonyl)-1H-indole-3-carboxamide from the sponge Zyzza massalis ${ }^{49}$ are the only natural products similar to splendamide (2). A number of more complex indole-3-carboximidamide-containing natural products have been reported from marine sponges, including the cytotoxic and antifungal nortopsentins A-C (23-25) from Spongosorites ruetzleri ${ }^{50}$ and nortopsentin D (26) from a Dragmacidon sp. ${ }^{51}$ (Figure 3).
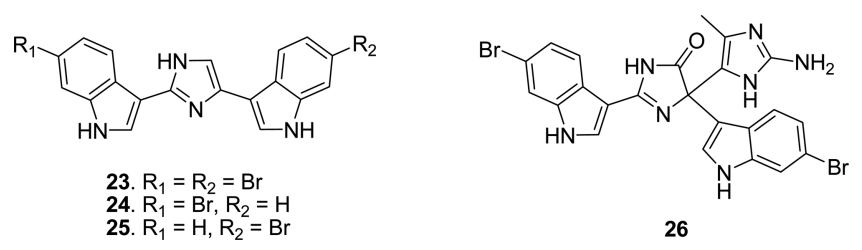

Figure 3. Chemical structures of nortopsentins A-D (23-26). 
Jaspnin A (3) TFA salt was isolated as a white powder. (+)-HRESIMS measurement gave an adduct ion at $\mathrm{m} / \mathrm{z}$ 223.0511 $[\mathrm{M}+\mathrm{Na}]^{+}$, consistent with a molecular formula of $\mathrm{C}_{8} \mathrm{H}_{12} \mathrm{~N}_{2} \mathrm{O}_{2} \mathrm{~S}$ with four degrees of unsaturation. The IR spectrum had an absorption at $1660 \mathrm{~cm}^{-1}$, suggesting a carbonyl functionality in the molecule. The UV spectrum had an absorption maximum at $208 \mathrm{~nm}$ and weak absorption at 244 $\mathrm{nm}$, indicative of an imidazole moiety. The ${ }^{1} \mathrm{H}$ NMR data (Table 3) contained one aromatic singlet $\left(\delta_{\mathrm{H}} 9.01\right)$, one

Table 3. NMR Spectroscopic Data (600 MHz for ${ }^{1} \mathrm{H}$ and 150 $\mathrm{MHz}$ for $\left.{ }^{13} \mathrm{C}, \mathrm{CD}_{3} \mathrm{OD}\right)$ for 3

$\begin{array}{lcccc}\text { position } & \delta_{\mathrm{C}} \text {, type } & \begin{array}{c}\delta_{\mathrm{H}}, \text { mult. }(\mathrm{H} \text { in } \\ \mathrm{Hz})\end{array} & \text { COSY } & \mathrm{HMBC}^{a} \\ 1 & 170.7, \mathrm{C} & & & \\ 2 & 28.9, \mathrm{C} & 4.01, \mathrm{~s} & & 1,3,4 \\ 3 & 134.3, \mathrm{C} & & & \\ 4 & 127.7, \mathrm{C} & & & \\ 6 & 139.7, \mathrm{CH} & 9.01, \mathrm{~s} & N^{5}-\mathrm{CH}_{3}, N^{7}-\mathrm{CH}_{3} & 3,4 \\ 4-\mathrm{SCH}_{3} & 17.8, \mathrm{CH}_{3} & 2.36, \mathrm{~s} & & 4 \\ 5-\mathrm{NCH}_{3} & 33.0, \mathrm{CH}_{3} & 3.97, \mathrm{~s} & \mathrm{H}_{6} & 4,6 \\ 7-\mathrm{NCH}_{3} & 33.9, \mathrm{CH}_{3} & 3.87, \mathrm{~s} & \mathrm{H}_{6} & 3,6\end{array}$

${ }^{a} \mathrm{HMBC}$ correlations are from proton(s) stated to the indicated carbon.

methylene singlet $\left(\delta_{\mathrm{H}} 4.01\right)$, and three methyl singlets $\left(\delta_{\mathrm{H}} 3.97\right.$, 3.87 , and 2.36) (Table 3). Five protonated carbons were identified in the HSQC and HMBC spectra. The chemical shifts of the two methyls $\left(\delta_{\mathrm{H}} 3.97\right.$ and $\delta_{\mathrm{C}} 33.0, \delta_{\mathrm{H}} 3.87$ and $\delta_{\mathrm{C}}$ 33.9) suggested that they were $N$-methyl groups. The third methyl singlet $\left(\delta_{\mathrm{H}} 2.34\right.$ and $\left.\delta_{\mathrm{C}} 17.8\right)$ was either an aromatic, olefinic, or $S$-methyl. The chemical shifts of the methine functionality $\left(\delta_{\mathrm{H}} 9.01\right.$ and $\left.\delta_{\mathrm{C}} 139.7\right)$ indicated a diheteroatomsubstituted $\mathrm{sp}^{2}$-hybridized methine.

HMBC correlations from the methine $\left(\delta_{\mathrm{H}}\right.$ 9.01) and the methylene $\left(\delta_{\mathrm{H}} 4.01\right)$ protons to two nonprotonated carbons $\left(\delta_{\mathrm{C}} 134.3\right.$ and 127.7) suggested the presence of a substituted imidazole moiety. Weak COSY correlations between the methine proton and two $N$-methyls indicated the presence of 1,3-dimethylimidazole. The assignment was confirmed by HMBC correlations from the two methyl singlets $\left(\delta_{\mathrm{H}} 3.94\right.$ and 3.87) to the methine carbon $\left(\delta_{\mathrm{C}} 139.7\right)$. An HMBC correlation from the methylene singlet $\left(\delta_{\mathrm{H}} 4.01\right)$ to a carbonyl carbon $\left(\delta_{\mathrm{C}} 170.7\right)$ suggested the presence of a carboxylic acid. The remaining elements were assigned a methyl thioether, and its attachment at C-4 was established based on the HMBC correlation from the methyl singlet $\left(\delta_{\mathrm{H}} 2.36\right)$ to carbon C-4 $\left(\delta_{\mathrm{C}}\right.$ 127.7). Jaspnin A was therefore assigned as 3 (Figure 4). Because TFA was used throughout the purification process, the counterion for jaspnin A (3) was trifluoroacetate.

A number of methylthioimidazole-containing natural products have been reported in the literature, including dysideanin A (27) from Dysidea sp., ${ }^{53}$ reticulatins A and B from Hyrtios reticulatus, ${ }^{52,53}$ leptoclinidamine C (28) from Leptoclinides durus, ${ }^{54}$ didemnolines A-D from Didemnum sp., ${ }^{55}$ hyrtiomanz-

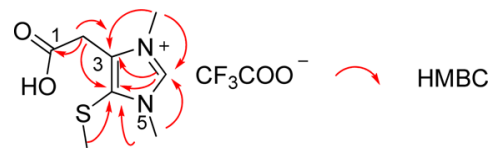

Figure 4. Key HMBC correlations for 3. amine from Hyrtios erecta, ${ }^{56}$ dragmacidonamines A and B from Dragmacidon sp., ${ }^{57}$ and gesashidine A from a Thorectidae sponge (Figure 5$).^{58}$

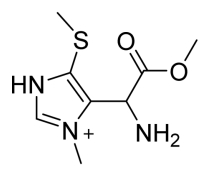

27<smiles></smiles>

28
Figure 5. Chemical structures of dysideanin A (27) and leptoclinidamine C (28).

Jaspamycin (8) and 6-bromo-1H-indole-3-carboximidamide (16) have been previously reported as synthetic products, and the spectra were identical with the data in the literature. ${ }^{29} 6$ Bromo- $1 \mathrm{H}$-indole-3-carboximidamide (16) is available commercially from Aurora Building Blocks. The 1D and 2D NMR data for $\mathbf{8}$ and $\mathbf{1 6}$ are given in the Supporting Information.

Consistent with the extraction and fractionation protocol developed in-house to prepare a Nature Bank fraction library targeting drug-like molecules, the isolated compounds were distributed within this lead-like space (five fractions in Figure 6). ${ }^{8,59}$ The physicochemical property calculations using Instant JChem (version 15.7.27.0) are in the Supporting Information. ${ }^{60}$

The cytological profiles of the 22 metabolites from $J$. splendens were examined to identify congeneric chemical series by coupling an unbiased multidimensional phenotype assay using nontransformed and nonimmortalized hONS cells, which are primary cells derived from a Parkinson's disease patient. hONS cells were treated with $10 \mu \mathrm{M}$ of each compound for 24 h. Cytological parameters were assessed by staining with fluorescent probes targeting various cellular pathways and organelles implicated in Parkinson's disease. These included mitochondria, early endosomes, lysosomes, microtubule-based cytoskeleton, and autophagosomes. In total, 38 phenotypic features across the individual cell line were generated. The compounds were subsequently clustered based on their pairwise Pearson's correlation coefficient using Cluster 3.0 and visualized using Java TreeView (Figure 7). At the concentration of $10 \mu \mathrm{M}$, compounds 18, 19, 21, and 22 showed cytotoxicity; hence they were not included in the heat map.

On the basis of the similarity of their biological profile, two prominent clusters were obtained by a defined line across the dendrogram at a Pearson's correlation of $>0.70$. Under a Pearson's correlation of 0.77 , there were four clusters, A, B, C, and $\mathrm{D}$ (Figures 7 and 8).

Jaspamycin (8) in cluster A showed the highest level of deviation from the control in the biological activity profile. Clustering of the 38 biological parameters resulted in a 3-modal effect. Nuclear and cytoplasmic markers were slightly affected compared to the DMSO control. Parameters associated with mitochondria, $\alpha$-tubulin, LC3b, and lysosome were moderately increased relative to the DMSO control, while an obvious decrease in the number of EEA1-associated early endosomes throughout the cytoplasm was evident with a corresponding increase in signal intensity. At a Pearson's correlation of 0.77 , five compounds, 1-3, 16, and 20, in cluster B were similar in the biological activity profile to jaspamycin (8) in cluster A, 


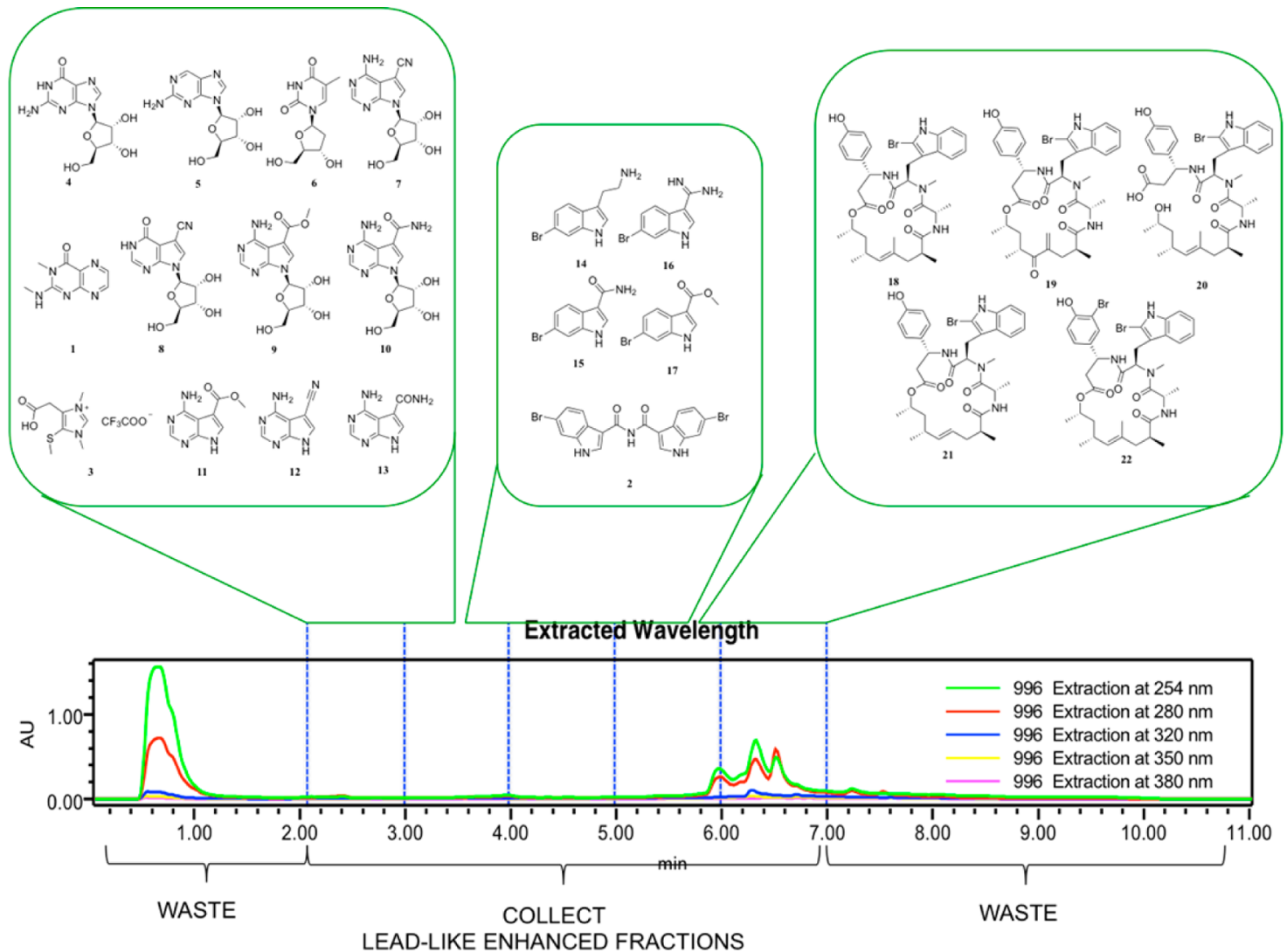

Figure 6. HPLC chromatogram of lead-like enhanced extract of the marine species Jaspis splendens and chemical structures isolated from different lead-like enhanced fractions.

with the main difference that cluster B showed a lower level of deviation from the control (Figures 7 and 8).

Compared to clusters $\mathrm{A}$ and $\mathrm{B}$, compounds in clusters $\mathrm{C}$ and $\mathrm{D}$ showed negative deviation from the control for mitochondria, $\alpha$-tubulin, LC3b, and lysosome features. In cluster C, cytoplasmic, mitochondrial, and autophagy markers with compounds 4-7, 10, and 14 were slightly decreased in comparison with compounds 9, 11-13, and 17 under a Pearson's correlation of 0.91 . The most striking and consistent alteration was the effect of these compounds on the early endosomal marker EEA1, which decreased in number and texture throughout the cytoplasm. Compound 15, a singleton in cluster $\mathrm{D}$, showed the lowest deviation from the DMSO control in its cytological profile.

Jaspamycin (8) in cluster A had previously been synthesized, and this is its first report as a natural product. As an analogue of toyocamycin (7), jaspamycin (8) had a very different cytological profile from the other six nucleosides $(4-7,9$, and 10) and three related aglycones $(11-13)$ in cluster C. Further analogues of jaspamycin 8 at positions 4 and 5 and the sugar moiety would allow a structure-activity relationship to be developed (Figure 8). The four other new metabolites 1-3 and 16 plus 20 in cluster B presented a relatively lower activity than jaspamycin (8). All six of these chemically diverse compounds were clustered into one prominent cluster and displayed similar phenotypic profiles.

In contrast, the four chemically similar bromoindole alkaloids 14-17 (clusters B, C, and D) were interestingly clustered into different groups, indicating that the substitutions for this scaffold played important roles in different therapeutic pathways or functional proteins.
In addition, the new bisindole alkaloid splendamide (2), with a carboxylic acid imide group, and the monoindole alkaloid 6bromo- $1 \mathrm{H}$-indole-3-carboximidamide (16), with a carboxamidine functionality, showed similar biological activity in cluster B. Under a Pearson's correlation of 0.91, they were in different clusters, revealing some structure-activity relationship.

Four of the five jaspamide peptides (18, 19, 21, and 22) exhibited an alteration of nuclear and cellular parameters at 10 $\mu \mathrm{M}$, suggesting that these cyclic jaspamide peptides are cytotoxic. Jaspamide $\mathrm{Z}_{1}(\mathbf{2 0})$, the open-chain form of jaspamide (18), showed a lower cytotoxicity level.

A new neighbor correlation of the phenotype to compounds with known biological targets may identify possible biological targets. Jaspamycin (8) had significant phenotypic perturbation of Parkinson's disease patient-derived human olfactory neurosphere-derived cells on the markers. In previous research, iotrochotazine A, isolated from an Australian marine sponge Iotrochota sp., was used as a chemical probe and investigated in the phenotypic assay. ${ }^{6}$ In comparison to iotrochotazine A, jaspamycin (8) moderately increased lysosomal staining and significantly decreased the number of EEA-1-associated early endosomes, while iotrochotazine A decreased lysosomal staining and increased the number of EEA-1-associated early endosomes. In conclusion, we have isolated three new compounds and two natural products, previously reported as synthetic products, together with 17 known metabolites from $J$. splendens. Rather than any unique chemical feature, it was the phenotypic responses of the metabolites in a hONS cell model of Parkinson's disease that led us to identify jaspamycin (8) as having unique biologically relevant chemical space. Herein, the different phenotypic responses of jaspamycin (8) and 


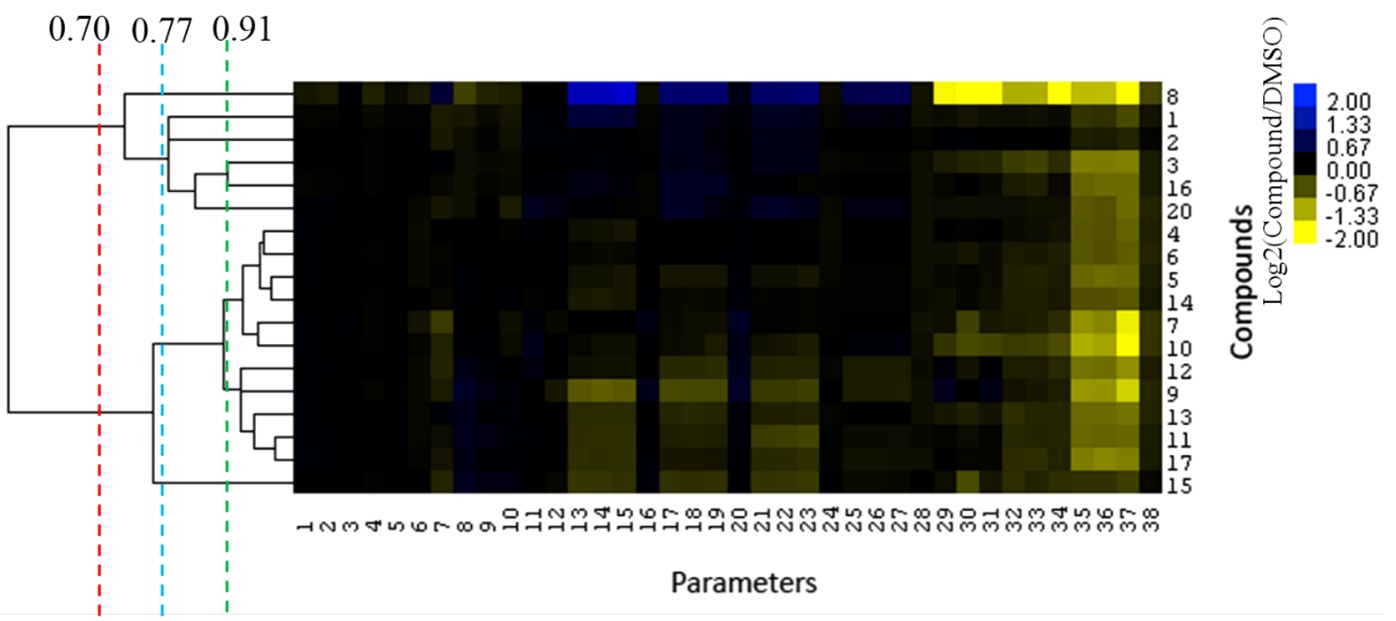

Figure 7. Heat map depicting the cytological profile of metabolites from Jaspis splendens at $10 \mu \mathrm{M}$ on 38 parameters based on the $\log _{2}$ ratio of compound and DMSO. Compounds were hierarchically clustered based on their pairwise Pearson coefficients. The effects of compounds were plotted as $\log _{2}$ ratio to the DMSO control. Yellow shows a decrease versus control, and blue shows an increase versus control. Individual compounds are presented on the $y$-axis with individual features on the $x$-axis. 1. Nucleus area $\left(\mu \mathrm{m}^{2}\right) .2$. Nucleus morphology width $(\mu \mathrm{m})$. 3. Nucleus morphology length $(\mu \mathrm{m})$. 4. Nucleus morphology ratio width to length. 5. Nucleus morphology roundness. 6. Nucleus marker texture index. 7. Nucleus marker intensity. 8. Cell area $\left(\mu \mathrm{m}^{2}\right)$. 9. Cell width $(\mu \mathrm{m})$. 10. Cell length $(\mu \mathrm{m})$ 11. Cell ratio width to length. 12. Cell roundness. 13. $\alpha$-Tubulin marker intensity in the cytoplasm. 14. $\alpha$-Tubulin marker intensity in outer region of cytoplasm. $15 . \alpha$-Tubulin marker intensity in inner region of cytoplasm. 16. $\alpha$-Tubulin marker texture index. 17. Mitochondria marker intensity in the cytoplasm. 18. Mitochondria marker intensity in outer region of cytoplasm. 19. Mitochondria marker intensity in inner region of the cytoplasm. 20. Mitochondria marker texture index. 21. LC3b marker intensity in the cytoplasm. 22. LC3b marker intensity in the outer region of the cytoplasm. 23. LC3b marker intensity in inner region of cytoplasm. 24. LC 3b marker texture index. 25. Lysosome marker intensity mean. 26. Lysosome marker intensity outer region mean. 27. Lysosome marker intensity inner region mean. 28. Lysosome marker texture index. 29. Number of EEA1 marker spots in cytoplasm. 30. Number of EEA1 marker spots in inner region of cytoplasm. 31. Number of EEA1 marker spots in outer region of cytoplasm. 32. Number of EEA1 marker spots per area of cytoplasm. 33. EEA1 marker intensity in outer region of cytoplasm. 34. EEA1 marker intensity in inner region of cytoplasm. 35 . EEA1 marker intensity in the cytoplasm. 36. Number of EEA1 marker spots per area of outer region. 37. Number of EEA1 marker spots per area of inner region of cytoplasm. 38. EEA1 marker texture index.

iotrochotazine A offer useful probes to investigate the molecular mechanisms underlying Parkinson's disease.

\section{EXPERIMENTAL SECTION}

General Experimental Procedures. Optical rotations were recorded on a JASCO P-1020 polarimeter $(10 \mathrm{~cm}$ cell). IR and UV spectra were recorded on a Bruker Tensor 27 spectrophotometer and a CAMSPEC M501 UV/vis spectrophotometer, respectively. NMR spectra were recorded in DMSO- $d_{6}\left(\delta_{\mathrm{H}} 2.50\right.$ and $\left.\delta_{\mathrm{C}} 39.5\right)$ or $\mathrm{MeOH}$ $d_{4}\left(\delta_{\mathrm{H}} 3.31\right.$ and $\left.\delta_{\mathrm{C}} 49.0\right)$ at $30{ }^{\circ} \mathrm{C}$ on a Varian INOVA $600 \mathrm{MHz}$ spectrometer equipped with a triple-resonance cold probe or at $25^{\circ} \mathrm{C}$ on a Bruker Avance HDX $800 \mathrm{MHz}$ spectrometer equipped with a TCI cryoprobe. The low-resolution mass spectrum (LRESIMS) was recorded on a Mariner time-of-flight (TOF) mass spectrometer equipped with a Gilson 215 eight-probe injector and a Waters LCMS system equipped with a Luna $\mathrm{C}_{18}$ column $(3 \mu \mathrm{m}, 100 \AA$, $50 \times 4.6$ $\mathrm{mm}$ ), a PDA detector, and a ZQ ESI mass spectrometer. Highresolution mass spectra (HRESIMS) were recorded on a Bruker Daltonics SolariX $12 \mathrm{~T}$ Fourier transform mass spectrometer. An Edwards Instrument Company Bioline orbital shaker was used for extraction. The HPLC system included a Waters 600 pump fitted with a 996 photodiode array detector and Gilson FC204 fraction collector. A ThermoElectron Betasil $\mathrm{C}_{18}$ column $(5 \mu \mathrm{m}, 21.2 \times 150 \mathrm{~mm})$ and a Phenomenex Luna $\mathrm{C}_{18}$ column $(5 \mu \mathrm{m}, 10 \times 250 \mathrm{~mm})$ were used for semipreparative HPLC. All solvents used for extraction, chromatography, $[\alpha]_{\mathrm{D}}$, UV, IR, and MS were Lab-Scan HPLC grade, and the $\mathrm{H}_{2} \mathrm{O}$ was Millipore Milli-Q PF filtered.

Animal Material. A specimen of Jaspis splendens was collected by scuba $(-23 \mathrm{~m}$ ) in Mid Reef (S 14.44813, E 144.88139), Great Barrier Reef, North Queensland, Australia, on July 3, 2003. Sponge material was kept frozen prior to freeze-drying and extraction. Taxonomic identification of J. splendens was performed by Dr. J. N. A. Hooper. A voucher specimen, G320726, has been deposited at the Queensland Museum, South Brisbane, Australia.

Extraction and Purification of Compounds 1-22. The ground and freeze-dried J. splendens $(50 \mathrm{~g})$ was extracted with $n$-hexane $(250$ $\mathrm{mL}$ ) for $2 \mathrm{~h}$ at room temperature (rt). The hexane extract was filtered under gravity and discarded. Then $250 \mathrm{~mL}$ of $\mathrm{CH}_{2} \mathrm{Cl}_{2} / \mathrm{MeOH}$ (80:20) was added to the biota and extracted for $2 \mathrm{~h}$. The $\mathrm{CH}_{2} \mathrm{Cl}_{2} / \mathrm{MeOH}$ extract was filtered, and the biota was further extracted with two lots of $250 \mathrm{~mL}$ of $\mathrm{MeOH}$ for $2 \mathrm{~h}$ and overnight, successively. Both $\mathrm{MeOH}$ extracts were combined with $\mathrm{CH}_{2} \mathrm{Cl}_{2} / \mathrm{MeOH}$ extract and dried to afford the crude extract. The crude extract was fractionated using a $\mathrm{C}_{18}$ bonded silica flash column. Five fractions were collected by eluting with gradients $\mathrm{H}_{2} \mathrm{O} / \mathrm{MeOH}$ containing $0.1 \%$ TFA $\left(100 \% \mathrm{H}_{2} \mathrm{O}, 90 \%\right.$ $\mathrm{H}_{2} \mathrm{O} / 10 \% \mathrm{MeOH}, 50 \% \mathrm{H}_{2} \mathrm{O} / 50 \% \mathrm{MeOH}, 10 \% \mathrm{H}_{2} \mathrm{O} / 90 \% \mathrm{MeOH}$, $100 \% \mathrm{MeOH}$, respectively). The $90 \% \mathrm{H}_{2} \mathrm{O} / 10 \% \mathrm{MeOH}$ fraction was chromatographed by HPLC (gradient $\mathrm{H}_{2} \mathrm{O} / \mathrm{MeOH}$ with $0.1 \%$ TFA) using a semipreparative reversed-phase $\mathrm{C}_{18}$ Betasil column $(21.2 \mathrm{~mm}$ $\times 150 \mathrm{~mm}$ ). Initial isocratic conditions of $10 \% \mathrm{MeOH}$ were used for $10 \mathrm{~min}$; then a linear gradient from $10 \%$ to $50 \% \mathrm{MeOH}$ was performed over $40 \mathrm{~min}$ and continued isocratic for $10 \mathrm{~min}$ at a flow rate of $9 \mathrm{~mL} / \mathrm{min}$. Sixty fractions were collected by 1 min increments over $60 \mathrm{~min}$ to afford jaspterin (1) and jaspnin A (3) TFA salt, together with nucleosides (4-10) and aglycones (11-13). The 50\% $\mathrm{H}_{2} \mathrm{O} / 50 \% \mathrm{MeOH}$ fraction was chromatographed by HPLC (gradient $\mathrm{H}_{2} \mathrm{O} / \mathrm{MeOH}$ with $0.1 \%$ TFA) using the same semipreparative $\mathrm{C}_{18}$ column eluting with $70 \% \mathrm{H}_{2} \mathrm{O} / 30 \% \mathrm{MeOH}$ to $20 \% \mathrm{H}_{2} \mathrm{O} / 80 \% \mathrm{MeOH}$. A new bisindole alkaloid, splendamide (2), along with four indole alkaloids (14-17) were isolated. In addition, five jaspamide pepitides (18-22) were also isolated from the $90 \% \mathrm{H}_{2} \mathrm{O} / 10 \% \mathrm{MeOH}$ fraction by the same semipreparative HPLC column eluting with gradient $\mathrm{H}_{2} \mathrm{O} / \mathrm{MeOH}$ with $0.1 \%$ TFA from $40 \% \mathrm{H}_{2} \mathrm{O} / 60 \% \mathrm{MeOH}$ to $100 \%$ $\mathrm{MeOH}$.

Jaspterin (1): white powder; UV (MeOH) $\lambda_{\max }(\log \varepsilon) 238(2.81)$, 252 (2.81), 280 (2.89), 358 (2.43) nm; ${ }^{1} \mathrm{H}$ NMR (600 MHz, DMSO- 


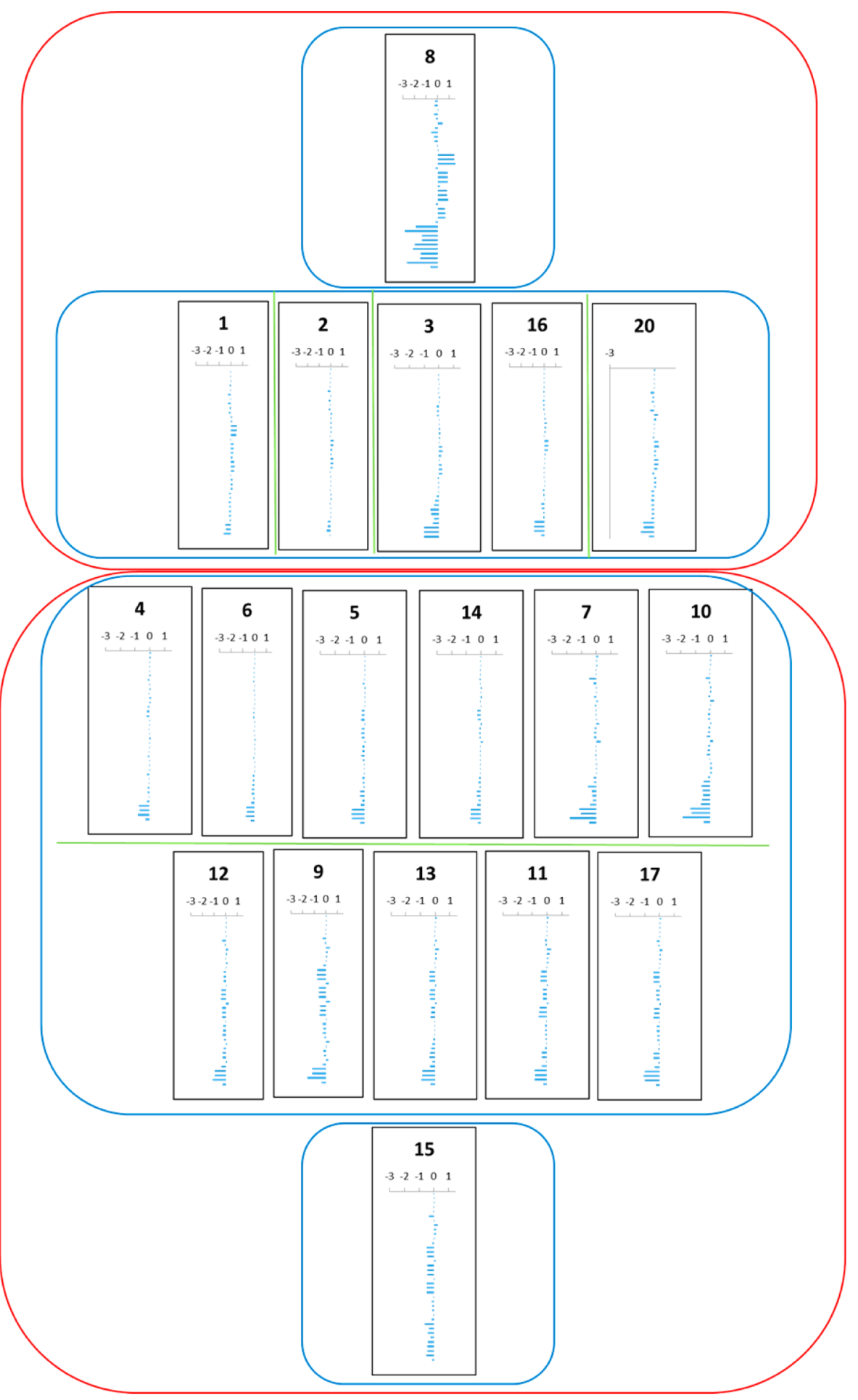

Figure 8. Clustered biological activity profile of metabolites from Jaspis splendens. The full description of all 38 cellular parameters and their response to natural products at $10 \mu \mathrm{M}(x$-axis: $\log 2$ ratio of metabolite $(10 \mu \mathrm{M})$ vs control (DMSO); $y$-axis: 38 cellular parameters). Two prominent clusters are shown in the red frames. Clusters A, B, C, and D are shown in the light blue frames. The light green lines show a Pearson's correlation of 0.91 .

$\left.d_{6}\right)$ and ${ }^{13} \mathrm{C}$ NMR data $\left(125 \mathrm{MHz}\right.$, DMSO- $\left.d_{6}\right)$, Table 1; (+)-HRESIMS $m / z 214.0670[\mathrm{M}+\mathrm{Na}]^{+}$(calcd for $\mathrm{C}_{8} \mathrm{H}_{9} \mathrm{~N}_{5} \mathrm{NaO}$, 214.0699).

Splendamide (2): colorless gum; UV $(\mathrm{MeOH}) \lambda_{\max }(\log \varepsilon) 216$ (3.60), 275 (3.19), 304 (2.97) nm; ${ }^{1} \mathrm{H}$ NMR (600 MHz, DMSO- $d_{6}$ ) and ${ }^{13} \mathrm{C}$ NMR data $\left(125 \mathrm{MHz}\right.$, DMSO- $\left.d_{6}\right)$, Table 2; (+)-HRESIMS $m / z 481.9116[\mathrm{M}+\mathrm{Na}]^{+}$(calcd for $\mathrm{C}_{18} \mathrm{H}_{11}{ }^{79} \mathrm{Br}_{2} \mathrm{~N}_{3} \mathrm{NaO}_{2}, 481.9110$ ). Jaspnin A (3) TFA salt: white powder; UV $(\mathrm{MeOH}) \lambda_{\max }(\log \varepsilon)$ 208 (2.88), $244(2.39) \mathrm{nm} ;{ }^{1} \mathrm{H}$ NMR $\left(600 \mathrm{MHz}, \mathrm{MeOH}-d_{4}\right)$ and ${ }^{13} \mathrm{C}$
NMR data (125 MHz, MeOH- $\left.d_{4}\right)$, Table 3; (+)-HRESIMS $\mathrm{m} / z$ 223.0511 $[\mathrm{M}+\mathrm{Na}]^{+}$(calcd for $\left.\mathrm{C}_{8} \mathrm{H}_{12} \mathrm{~N}_{2} \mathrm{NaO}_{2} \mathrm{~S}, 223.0511\right)$.

Jaspamycin (8): white solid; $[\alpha]_{\mathrm{D}}^{26}-25.0(c 0.020, \mathrm{MeOH})$; UV $(\mathrm{MeOH}) \lambda_{\max }(\log \varepsilon) 208$ (4.09), 265 (3.94) nm; ${ }^{1} \mathrm{H}$ NMR (600 MHz, DMSO-d $\left.d_{6}\right) 12.48(\mathrm{~s}, 1 \mathrm{H}), 8.33(\mathrm{~s}, 1 \mathrm{H}), 8.08(\mathrm{~s}, 1 \mathrm{H}), 6.02$ (d, 5.5, $1 \mathrm{H}), 4.31$ (dd, 5.5, 5.1, 1H), 4.09 (dd, 5.1, 3.9, $1 \mathrm{H}), 3.92(\mathrm{~m}, 1 \mathrm{H})$, 3.65(dd, 12.3, 2.9, 1H), 3.57 (dd, 12.3, 3.2, $1 \mathrm{H}) ;(+)$-HRESIMS $\mathrm{m} / \mathrm{z}$ $315.0700[\mathrm{M}+\mathrm{Na}]^{+}$(calcd for $\left.\mathrm{C}_{12} \mathrm{H}_{12} \mathrm{~N}_{4} \mathrm{NaO}_{5}, 315.0700\right)$. 
6-Bromo-1H-indole-3-carboximidamide (16) TFA salt: white powder; UV $(\mathrm{MeOH}) \lambda_{\max }(\log \varepsilon) 235(4.28), 290(3.65) \mathrm{nm} ;{ }^{1} \mathrm{H}$ NMR $\left(600 \mathrm{MHz}\right.$, DMSO- $\left.d_{6}\right) 12.38(\mathrm{~s}, \mathrm{br}, 1 \mathrm{H}), 8.79(\mathrm{~s}, \mathrm{br}, 2 \mathrm{H}), 8.50$ (s, br, 2H), $8.22(\mathrm{~s}, \mathrm{br}, 1 \mathrm{H}), 7.79(\mathrm{~d}, 1.8,1 \mathrm{H}), 7.76(\mathrm{~d}, 8.6,1 \mathrm{H}), 7.41$ (dd, 1.8, 8.6, $1 \mathrm{H})$; $(+)$-HRESIMS $m / z 237.9974[\mathrm{M}+\mathrm{H}]^{+}$(calcd for $\left.\mathrm{C}_{9} \mathrm{H}_{8}{ }^{79} \mathrm{BrN}_{3}, 237.9980\right)$.

Biological Assay. Compounds were transferred into two optically clear bottom CellCarrier 384-well plates (PerkinElmer). hONS cells from the Parkinson's disease cell line C1 200080013 were added to each well at a density of 1350 cells per well in $50 \mu \mathrm{L}$ of growth medium (DMEM/F12, 10\% FBS) leading to a final concentration of $10 \mu \mathrm{M}(0.6 \% \mathrm{DMSO})$ for each compound. DMSO (0.6\%) was used as negative control. The cells were incubated for $24 \mathrm{~h}$ at $37{ }^{\circ} \mathrm{C}$ under $5 \%$ $\mathrm{CO}_{2}$

Cell Staining. After $24 \mathrm{~h}$ of incubation, the medium was aspirated, and one 384-well plate was treated with MitoTracker Orange CMTMRos (Invitrogen) $(400 \mathrm{nM})$ for $30 \mathrm{~min}$ at $37{ }^{\circ} \mathrm{C}$ under $5 \%$ $\mathrm{CO}_{2}$. The second 384-well plate was treated with LysoTracker Red DND-99 (Invitrogen) $(100 \mathrm{nM})$ for $1 \mathrm{~h}$ at $37^{\circ} \mathrm{C}$ under $5 \% \mathrm{CO}_{2}$. Cells were fixed in $4 \%$ paraformaldehyde for $5 \mathrm{~min}$ at rt. Cells were washed twice with phosphate-buffered saline (PBS, Sigma-Aldrich) and treated with $3 \%$ goat serum (Sigma-Aldrich) and 0.2\% Triton X-100 (SigmaAldrich) in PBS for $45 \mathrm{~min}$ at rt. Plates were incubated with primary antibodies. Mouse anti- $\alpha$-tubulin 1/4000 (Sigma-Aldrich) and rabbit anti-LC3b 1/335 (Sigma-Aldrich) were added to the plate already treated with MitoTracker, and mouse anti-EEA1 1/200 (SigmaAldrich) was added to the plate previously treated with LysoTracker. Plates were incubated at $\mathrm{rt}$ for $1 \mathrm{~h}$, then washed twice with PBS. Secondary antibodies goat anti-mouse Alexa-647 1/500 (Invitrogen) and goat anti-rabbit Alexa-488 1/500 (Invitrogen) were added to the first plate, and goat anti-mouse Alexa-488 1/500 (Invitrogen) was added to the second plate for $30 \mathrm{~min}$ at rt. Cells were washed twice with PBS and stained with 4',6'-diamidino-2-phenylindole 1/5000 (Dapi, Invitrogen) and with CellMask Deep Red 1/5000 (Invitrogen) for the plate treated with LysoTracker and incubated for $10 \mathrm{~min}$ at rt. Cells were washed twice with PBS, and plates were stored in the dark at $4{ }^{\circ} \mathrm{C}$ with $25 \mu \mathrm{L}$ of PBS/well.

Imaging and Image Analysis. Plates were imaged automatically using Operetta (PerkinElmer), a high content imaging system using a $20 \times$ high numerical aperture objective lens. Six images per well for each wavelength were collected. Individual cell segmentation was done using the Harmony software, and measurements for each cell were performed generating 38 parameters from six dyes: Dapi, $\alpha$-tubulin staining, MitoTracker Orange CMTMRos, LC3b staining, LysoTracker Red DND-99, and EEA1 staining. The normality of the data was checked for each parameter, and a $\log _{2}$ transform was made when required in order to perform a $t$-test to identify significant changes when compared to DMSO. The $\log _{2}$ compound/DMSO ratio was clustered using Cluster 3.0 software (uncentered correlation and centroid linkage) and analyzed using Java TreeView.

\section{ASSOCIATED CONTENT}

\section{(S Supporting Information}

The Supporting Information is available free of charge on the ACS Publications website at DOI: 10.1021/acs.jnatprod.5b00987.

1D and 2D NMR spectra for compounds 1-3, 8, and 16 (PDF)

\section{AUTHOR INFORMATION}

\section{Corresponding Author}

*Tel: +64 73735 6009. E-mail: r.quinn@griffith.edu.au.

\section{Notes}

The authors declare no competing financial interest.

\section{ACKNOWLEDGMENTS}

This research was supported by Australian Research Council Discovery Projects funding (project number DP130102400) and the Clem Jones Foundation. D.W. thanks Griffith University for a GUIPRS scholarship.

\section{REFERENCES}

(1) Macarron, R; Banks, M. N.; Bojanic, D.; Burns, D. J.; Cirovic, D. A.; Garyantes, T.; Green, D. V.; Hertzberg, R. P.; Janzen, W. P.; Paslay, J. W. Nat. Rev. Drug Discovery 2011, 10, 188-195.

(2) Swinney, D. C.; Anthony, J. Nat. Rev. Drug Discovery 2011, 10, 507-519.

(3) Olanow, C. W.; Stern, M. B.; Sethi, K. Neurology 2009, 72, S1S136.

(4) Matigian, N.; Abrahamsen, G.; Sutharsan, R.; Cook, A. L.; Vitale, A. M.; Nouwens, A.; Bellette, B.; An, J.; Anderson, M.; Beckhouse, A. G. Dis. Models \&amp; Mech. 2010, 3, 785-798.

(5) Cook, A. L.; Vitale, A. M.; Ravishankar, S.; Matigian, N.; Sutherland, G. T.; Shan, J.; Sutharsan, R.; Perry, C.; Silburn, P. A.; Mellick, G. D. PLoS One 2011, 6, e21907.

(6) Grkovic, T.; Pouwer, R. H.; Vial, M. L.; Gambini, L.; Noel, A.; Hooper, J. N.; Wood, S. A.; Mellick, G. D.; Quinn, R. J. Angew. Chem., Int. Ed. 2014, 53, 6070-6074.

(7) Harvey, A. L.; Edrada-Ebel, R.; Quinn, R. J. Nat. Rev. Drug Discovery 2015, 14, 111-129.

(8) Camp, D.; Davis, R. A.; Campitelli, M.; Ebdon, J.; Quinn, R. J. J. Nat. Prod. 2012, 75, 72-81.

(9) Feng, Y.; Campitelli, M.; Davis, R. A.; Quinn, R. J. Mar. Drugs 2014, 12, 1169-1184.

(10) Ebada, S. S.; Wray, V.; de Voogd, N. J.; Deng, Z.; Lin, W.; Proksch, P. Mar. Drugs 2009, 7, 434-444.

(11) Gala, F.; D’Auria, M. V.; De Marino, S.; Zollo, F.; Smith, C. D.; Copper, J. E.; Zampella, A. Tetrahedron 2007, 63, 5212-5219.

(12) Gala, F.; D’Auria, M. V.; De Marino, S.; Sepe, V.; Zollo, F.; Smith, C. D.; Copper, J. E.; Zampella, A. Tetrahedron 2008, 64, 71277130.

(13) Gala, F.; D’Auria, M. V.; De Marino, S.; Sepe, V.; Zollo, F.; Smith, C. D.; Keller, S. N.; Zampella, A. Tetrahedron 2009, 65, 51-56.

(14) Ravi, B.; Wells, R. J.; Croft, K. D. J. Org. Chem. 1981, 46, 19982001.

(15) Tsuda, M.; Ishibashi, M.; Agemi, K.; Sasaki, T.; Kobayashi, J. i. Tetrahedron 1991, 47, 2181-2194.

(16) Kobayashi, J. i.; Yuasa, K.; Kobayashi, T.; Sasaki, T.; Tsuda, M. Tetrahedron 1996, 52, 5745-5750.

(17) Kobayashi, J. i.; Murata, O.; Shigemori, H.; Sasaki, T. J. Nat. Prod. 1993, 56, 787-791.

(18) Rodríguez, J.; Nieto, R. M.; Crews, P. J. Nat. Prod. 1993, 56, 2034-2040.

(19) Searle, P. A.; Richter, R. K.; Molinski, T. F. J. Org. Chem. 1996, 61, 4073-4079.

(20) D’Auria, M. V.; Giannini, C.; Minale, L.; Zampella, A.; Debitus, C.; Frostin, M. J. Nat. Prod. 1997, 60, 814-816.

(21) Groweiss, A.; Newcomer, J. J.; O’Keefe, B. R.; Blackman, A.; Boyd, M. R. J. Nat. Prod. 1999, 62, 1691-1693.

(22) Thale, Z.; Kinder, F. R; Bair, K. W.; Bontempo, J.; Czuchta, A. M.; Versace, R. W.; Phillips, P. E.; Sanders, M. L.; Wattanasin, S.; Crews, P. J. Org. Chem. 2001, 66, 1733-1741.

(23) Park, Y.; Liu, Y.; Hong, J.; Lee, C.-O.; Cho, H.; Kim, D.-K.; Im, K. S.; Jung, J. H. J. Nat. Prod. 2003, 66, 1495-1498.

(24) Shinde, P. B.; Lee, Y. M.; Dang, H. T.; Hong, J.; Lee, C.-O.; Jung, J. H. Bioorg. Med. Chem. Lett. 2008, 18, 6414-6418.

(25) Zabriskie, T. M.; Ireland, C. M. J. Nat. Prod. 1989, 52, 13531356.

(26) Ohta, S.; Kobayashi, H.; Ikegami, S. Tetrahedron Lett. 1994, 35, $4579-4580$.

(27) Ohta, S.; Kobayashi, H.; Ikegami, S. Biosci., Biotechnol., Biochem. 1994, 58, 1752-1753. 
(28) Chang, Y. H.; Shin, D.; Na, Z.; Lee, H.-S.; Kim, D.-D.; Oh, K.B.; Shin, J. J. Nat. Prod. 2008, 71, 779-783.

(29) Hinshaw, B. C.; Gerster, J. F.; Robins, R. K.; Townsend, L. B. J. Org. Chem. 1970, 35, 236-241.

(30) Broom, A. D.; Robins, R. K. J. Org. Chem. 1969, 34, 1025-1029.

(31) Nair, V.; Young, D. A.; DeSilvia, R., Jr J. Org. Chem. 1987, 52, 1344-1347.

(32) Fox, J.; Wempen, I. Adv. Carbohydr. Chem. 1959, 14, 283.

(33) Chenon, M. T.; Pugmire, R. J.; Grant, D. M.; Panzica, R. P.; Townsend, L. B. J. Am. Chem. Soc. 1975, 97, 4627-4636.

(34) Rao, K. V. J. Med. Chem. 1968, 11, 939-941.

(35) Fahy, E.; Potts, B. C.; Faulkner, D. J.; Smith, K. J. Nat. Prod. 1991, 54, 564-569.

(36) Wang, R.-P.; Lin, H.-W.; Li, L.-Z.; Gao, P.-Y.; Xu, Y.; Song, S.J. Biochem. Syst. Ecol. 2012, 43, 210-213.

(37) Segraves, N. L.; Crews, P. J. Nat. Prod. 2005, 68, 1484-1488.

(38) Zabriskie, T. M.; Klocke, J. A.; Ireland, C. M.; Marcus, A. H.; Molinski, T. F.; Faulkner, D. J.; Xu, C.; Clardy, J. J. Am. Chem. Soc. 1986, 108, 3123-3124.

(39) Zampella, A.; Giannini, C.; Debitus, C.; Roussakis, C.; D’Auria, M. V. J. Nat. Prod. 1999, 62, 332-334.

(40) Watts, K. R.; Morinaka, B. I.; Amagata, T.; Robinson, S. J.; Tenney, K.; Bray, W. M.; Gassner, N. C.; Lokey, R. S.; Media, J.; Valeriote, F. A.; Crews, P. J. Nat. Prod. 2011, 74, 341-351.

(41) Sorres, J.; Martin, M. T.; Petek, S.; Levaique, H.; Cresteil, T.; Ramos, S.; Thoison, O.; Debitus, C.; Al-Mourabit, A. J. Nat. Prod. 2012, 75, 759-763.

(42) McArdle, B. M.; Campitelli, M. R.; Quinn, R. J. J. Nat. Prod. 2006, 69, 14-17.

(43) Kellenberger, E.; Hofmann, A.; Quinn, R. J. Nat. Prod. Rep. 2011, 28, 1483-1492.

(44) Feng, Y.; Davis, R. A.; Sykes, M. L.; Avery, V. M.; Quinn, R. J. Bioorg. Med. Chem. Lett. 2012, 22, 4873-4876.

(45) Feng, Y.; Carroll, A. R.; Pass, D. M.; Archbold, J. K.; Avery, V. M.; Quinn, R. J. J. Nat. Prod. 2008, 71, 8-11.

(46) Kim, S.; Kang, Y. Bull. Korean Chem. Soc. 2011, 32, 3161-3163.

(47) Sakurai, A.; Goto, M. J. Biochem. (Tokyo) 1967, 61, 142-145.

(48) Teng, J.; Yang, X. W. Heterocycles 2006, 68, 1691-1698.

(49) Mancini, I.; Guella, G.; Pietra, F.; Debitus, C.; Duhet, D. Helv. Chim. Acta 1994, 77, 1886-1894.

(50) Sakemi, S.; Sun, H. H. J. Org. Chem. 1991, 56, 4304-4307.

(51) Mancini, I.; Guella, G.; Pietra, F.; Debitus, C.; Waikedre, J. Helv. Chim. Acta 1996, 79, 2075-2082.

(52) Ren, S.; Ma, W.; Xu, T.; Lin, X.; Yin, H.; Yang, B.; Zhou, X.-F.; Yang, X.-W.; Long, L.; Lee, K. J. J. Antibiot. 2010, 63, 699-701.

(53) Imada, K.; Sakai, E.; Kato, H.; Kawabata, T.; Yoshinaga, S.; Nehira, T.; Terasawa, H.; Tsukamoto, S. Tetrahedron 2013, 69, 70517055.

(54) Carroll, A. R.; Avery, V. M. J. Nat. Prod. 2009, 72, 696-699.

(55) Schumacher, R. W.; Davidson, B. S. Tetrahedron 1995, 51, 10125-10130.

(56) Bourguet-Kondracki, M.; Martin, M.; Guyot, M. Tetrahedron Lett. 1996, 37, 3457-3460.

(57) Pedpradab, S.; Edrada, R.; Ebel, R.; Wray, V.; Proksch, P. J. Nat. Prod. 2004, 67, 2113-2116.

(58) Iinuma, Y.; Kozawa, S.; Ishiyama, H.; Tsuda, M.; Fukushi, E.; Kawabata, J.; Fromont, J.; Kobayashi, J. i. J. Nat. Prod. 2005, 68, 11091110.

(59) Quinn, R. J.; Carroll, A. R.; Pham, N. B.; Baron, P.; Palframan, M. E.; Suraweera, L.; Pierens, G. K.; Muresan, S. J. Nat. Prod. 2008, 71, 464-468.

(60) Instant JChem, version 15. 7.27.0; ChemAxon Kft: Budapest, Hungary, 2015. 